\title{
Investigation of Noncovalent Complexes Between $\beta$-Cyclodextrin and Polyamide Acids Containing $N$-Methylpyrrole and $N$-Methylimidazole by Electrospray Ionization Mass Spectrometry
}

\author{
Huihui Li, Jiang Zhou, Feili Tang, and Gu Yuan \\ Department of Chemical Biology, Key Laboratory of Bioorganic Chemistry and Molecular Engineering of the \\ Ministry of Education, College of Chemistry, Peking University, Beijing, China
}

\begin{abstract}
Electrospray ionization (ESI) mass spectrometry was utilized to investigate noncovalent complexes between $\beta$-cyclodextrin $(\beta$-CD) and five novel polyamide acids containing $N$ methylpyrrole and $N$-methylimidazole. The 1:1 binding mode was specified by examining the binding stoichiometry from ESI mass spectra. It found that polyamide acids with $\beta$-CD have binding affinities in the order: $\operatorname{Im} \operatorname{Im} \operatorname{Im} \beta \mathrm{COOH}>\operatorname{ImPy} \operatorname{Im} \beta \mathrm{COOH}>\operatorname{ImPyPy} \beta C O O H>$ PyPyPy $\beta \mathrm{COOH}>\mathrm{NO}_{2} \mathrm{PyPyPy} \beta \mathrm{COOH}$. The method gives, simultaneously, the binding constants between $\beta$-CD and polyamide acids based on a novel linear equation. (J Am Soc Mass Spectrom 2006, 17, 9-14) (C) 2005 American Society for Mass Spectrometry
\end{abstract}

$\mathrm{R}$ ecently, polyamides containing $N$-methylpyrrole (Py) and $N$-methylimidazole (Im) have attracted considerable attention from synthetic and biological chemists because of their significant anticancer activity $[1,2]$. Five new polyamide acids were synthesized in our laboratory with a convenient method for solution-phase synthesis [3]. Their structures are shown in Figure 1, where Py $=N$-methylpyrrole, $\mathrm{Im}=N$ methylimidazole, and $\beta=\beta$-alanine.

$\beta$-Cyclodextrin $(\beta$-CD or CD) is a very important host molecule. Noncovalent complexes between drug molecules and $\beta$-cyclodextrin are capable of improving the stability, water solubility, and bioavailability of some lipophilic drugs [4-10]. Therefore, $\beta-C D$ and its derivatives have been utilized in agriculture, pharmaceutics, drug formulation, and drug delivery.

A number of different physicochemical methods have been used in analyzing the interactions between small molecules and $\beta$-cyclodextrin, such as ${ }^{1} \mathrm{H}$ NMR, conductometric titration, spectrophotometric and fluorometric techniques [11-16]. However, in some instances, there are uncertainties regarding the complex stoichiometries and the lack of structural information using these techniques [17]. Electrospray ionization mass spectrometry (ESI-MS) is a powerful means of studying noncovalent complexes between "host-guest" (for example, small molecules with $\beta$-cyclodextrin) with

Published online December 9, 2005

Address reprint requests to Dr. G. Yuan, Department of Chemical Biology, Key Laboratory of Bioorganic Chemistry and Molecular Engineering of the Ministry of Education, College of Chemistry, Peking University, Beijing 100871, China. E-mail: guyuan@pku.edu.cn high sensitivity and rapidity, at a very low level of sample consumption [18-34].

In this research, ESI-MS was utilized to study the noncovalent interactions of five novel polyamide acids with $\beta$-cyclodextrin, including stoichiometry, stability and binding affinity, and calculation of the binding constants between $\beta-\mathrm{CD}$ and polyamide acids.

\section{Experimental}

\section{Chemicals}

$\beta$-Cyclodextrin ( $\mathrm{MW}=1134.4)$ was purchased from Sigma Chemical (St. Louis, MO). Polyamide acids $\left(\mathbf{P}_{\mathbf{1}^{-}}\right.$ $\mathbf{P}_{5}$ ) were prepared in our laboratory according to a convenient method for solution-phase synthesis [3]. All other chemicals were of analytical grade.

\section{Mass spectrometry}

ESI mass spectra and collision-induced dissociation (CID) spectra were obtained using a Finnigan LCQ Deca XP Plus ion-trap mass spectrometer (ThermoFinnigan, San Jose, CA); all experiments were performed in negative mode. The mixed solution was directly infused at a flow rate of $2 \mu \mathrm{l} / \mathrm{min}$ into the ion source. ESI-MS conditions were optimized to favor the observation of noncovalent complexes. Spray voltage was $3.0 \mathrm{kV}$, capillary temperature held at $150{ }^{\circ} \mathrm{C}$, and a doubled drying gas $\left(\mathrm{N}_{2}\right)$ was used to ensure efficient 
<smiles></smiles>

$\mathbf{R}=\mathrm{H}, \mathrm{X}=\mathrm{N}, \mathrm{Y}=\mathrm{N}, \mathrm{Z}=\mathrm{N}: \operatorname{Im} \operatorname{Im} \operatorname{Im} \beta \operatorname{COOH}\left(\mathrm{P}_{1}\right)$

$\mathrm{X}=\mathrm{N}, \mathrm{Y}=\mathrm{C}, \mathrm{Z}=\mathrm{N}: \operatorname{ImPy} \operatorname{Im} \beta \operatorname{COOH}\left(\mathbf{P}_{2}\right)$

$\mathrm{X}=\mathrm{N}, \mathrm{Y}=\mathrm{C}, \mathrm{Z}=\mathrm{C}: \operatorname{ImPyPy} \beta \operatorname{COOH}\left(\mathrm{P}_{3}\right)$

$\mathrm{X}=\mathrm{C}, \mathrm{Y}=\mathrm{C}, \mathrm{Z}=\mathrm{C}: \operatorname{PyPyPy} \beta \mathrm{COOH}\left(\mathrm{P}_{4}\right)$

\section{$\mathrm{R}=\mathrm{NO}_{2}, \mathrm{X}=\mathrm{C}, \mathrm{Y}=\mathrm{C}, \mathrm{Z}=\mathrm{C}: \mathrm{NO}_{2} \mathrm{PyPyPy} \beta \mathrm{COOH}\left(\mathrm{P}_{5}\right)$}

Figure 1. Structures of polyamide acids $\left(\mathbf{P}_{\mathbf{n}}\right)$.

desolvation. Data were collected and analyzed with the Xcalibur software (ThermoFinnigan), and 10 scans were averaged for each spectrum.

\section{Analysis of Complexation Procedure}

Noncovalent interactions of polyamide acids $\left(\mathbf{P}_{\mathbf{1}}-\mathbf{P}_{5}\right)$ with $\beta$-CD were examined by ESI mass spectrometry in the presence of increasing concentrations of $\beta$-CD. Aliquots of $0.5-25 \mu \mathrm{l} \beta$-CD $(5.0 \mathrm{mM})$ were mixed with $0.5 \mu$ l of polyamide acids $(5.0 \mathrm{mM})$. This solution was diluted with methanol/ $\mathrm{H}_{2} \mathrm{O}(20: 80, \mathrm{vol} / \mathrm{vol})$ to $50 \mu \mathrm{l}$ at room temperature $(\beta-\mathrm{CD}$-guest ratios were $1: 1,2: 1,5: 1$, 10:1, 25:1, and 50:1) and then subjected to ESI-MS analyses. Methanol was necessary to obtain good electrospray behavior $[35,36]$. All solutions had appropriate concentrations $(50-2500 \mu \mathrm{M})$ of $\beta$-CD and the same initial concentration $(50 \mu \mathrm{M})$ of polyamide.

\section{Results and Discussion}

\section{Complexes Between $\beta$-Cyclodextrin and Polyamide Acids}

Complexes of $\beta$-CD with polyamide acids in the molar ratio 1:1 were detected by negative ion mode; the ESI mass spectra of the three complexes are shown in Figure 2. In the case of $\operatorname{Im} \operatorname{Im} \operatorname{Im} \beta \mathrm{COOH}\left(\mathbf{P}_{\mathbf{1}}\right)$, five ions were observed in the ESI spectrum, i.e., ions at $\mathrm{m} / \mathrm{z}$ 442.3, 566.6, 885.0, 1133.6, and 1576.5, which correspond to $[\operatorname{ImImIm} \beta C O O]^{-}\left(\left[\mathrm{P}_{1}\right]^{-}\right), \quad[\beta-\mathrm{CD}]^{2-}\left([\mathrm{CD}]^{2-}\right)$, $[2 \operatorname{Im} \operatorname{ImIm} \beta \mathrm{COO}]^{-}\left(\left[2 \mathrm{P}_{1}\right]^{-}\right),[\beta-\mathrm{CD}]^{-}\left([\mathrm{CD}]^{-}\right),[\mathrm{com}-$ plex $]^{-}\left(\left[\mathrm{CD}+\mathrm{P}_{1}\right]^{-}\right)$of $\operatorname{ImImIm} \beta \mathrm{COOH}$ and $\beta-\mathrm{CD}$, respectively.

ESI mass spectra of complexes of $\beta$-CD with polyamide acids show that, in the case of $\mathbf{P}_{\mathbf{1}}$ and $\mathbf{P}_{\mathbf{2}}$, the abundance of $\left[C D+P_{n}\right]^{-}$ions is much greater than that of $\left[\mathrm{P}_{n}\right]^{-}$, while the abundance of $\left[\mathrm{CD}+\mathrm{P}_{5}\right]^{-}$is less than that of $\left[\mathrm{P}_{5}\right]^{-}$. This result suggests that the $N$-methylimidazole (Im) ring in polyamide acids is more favorable for binding with $\beta$-CD than the
$\mathrm{N}$-methylpyrrole (Py) ring. The $\mathrm{N}$-methylimidazole (Im) moiety has more nitrogen atoms than N-methylpyrrol (Py) and, therefore, more interactions, via hydrogen bonding, take place between polyamide acids containing the imidazole group and $\beta$-CD. In addition, the existence of nitryl at the end of the polyamides is unfavorable for binding, because it counteracts the superior hydrophobic interactions between $\beta$-CD and polyamides.

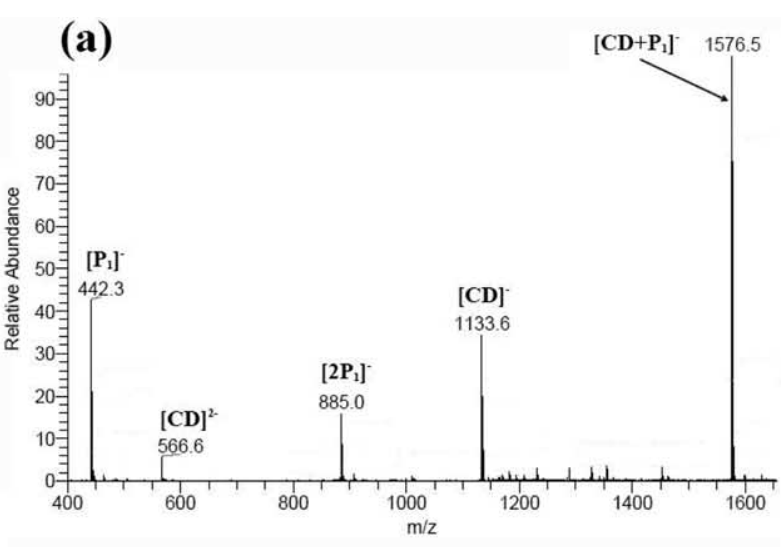

(b)

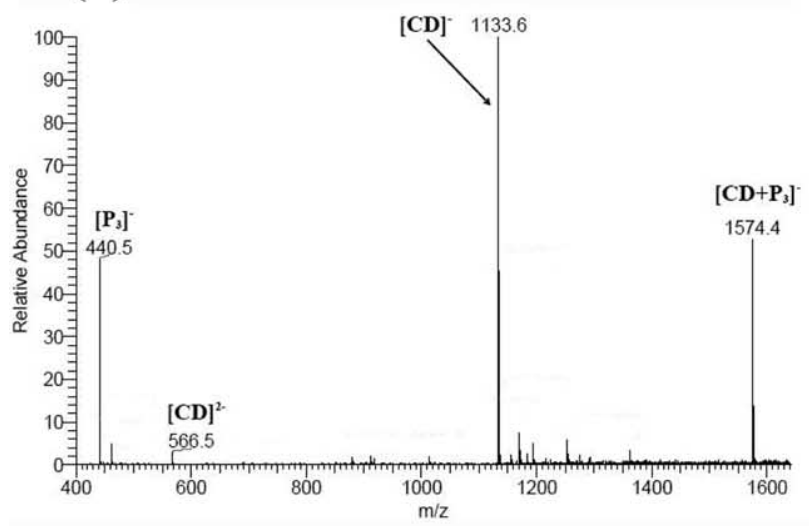

(c)

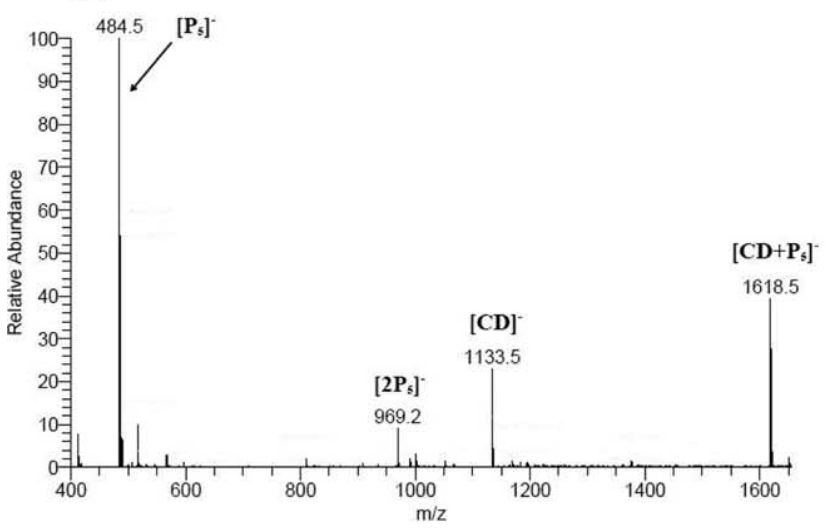

Figure 2. ESI mass spectra of equimolar mixtures of $\beta$-CD with (a) $\operatorname{ImImIm} \beta \mathrm{COOH}\left(\mathbf{P}_{\mathbf{1}}\right)$, (b) $\operatorname{ImPyPy} \beta \mathrm{COOH}\left(\mathbf{P}_{3}\right)$, and (c) $\mathrm{NO}_{2} \mathrm{PyPyPy} \beta \mathrm{COOH}\left(\mathbf{P}_{5}\right)$. 
Table 1. Effect of $\beta$-CD: $\mathrm{P}_{2}$ ratio on abundance

\begin{tabular}{cccc}
\hline $\begin{array}{c}\text { Molar } \\
\text { ratio }\end{array}$ & {$\left[\mathrm{P}_{2}\right]^{-}(\%)$} & {$\left[\mathrm{CD}+\mathrm{P}_{2}\right]^{-}(\%)$} & $\frac{\left[\mathrm{CD}+\mathrm{P}_{2}\right]^{-} \%}{\left[\mathrm{P}_{2}\right]^{-} \%+\left[\mathrm{CD}+\mathrm{P}_{2}\right]^{-} \%}$ \\
\hline \hline $1: 1$ & 51 & 100 & 0.66 \\
$2: 1$ & 30 & 100 & 0.77 \\
$5: 1$ & 18 & 100 & 0.85 \\
$10: 1$ & 12 & 100 & 0.91 \\
$25: 1$ & 7 & 77 & 0.93 \\
$50: 1$ & 3 & 58 & 0.96 \\
\hline
\end{tabular}

Effects of $\beta$-CD Concentration on Relative Intensities of the Respective Complex

Complexes of $\beta$-CD with each polyamide acid, at molar ratios ranging from $1: 1$ to $50: 1$, were analyzed by ESI-MS in the negative mode. As an example, the effect on binding of $\beta$-CD: ImPyIm $\beta \mathrm{COOH}\left(\mathbf{P}_{2}\right)$ molar ratios is listed in Table 1, in which relative abundances listed were normalized to $100 \%$ for each spectrum.

Table 1 shows that the abundance of polyamide acid decreased gradually when the molar ratio of $\beta$-CD to polyamide acid increased from 1:1 to 50:1. Here, $\frac{\left[\mathrm{CD}+\mathrm{P}_{\mathrm{n}}\right]^{-} \%}{\left[\mathrm{P}_{\mathrm{n}}\right]^{-} \%+\left[\mathrm{CD}+\mathrm{P}_{\mathrm{n}}\right]^{-} \%}$ (the relative intensity of the complex ion $\left(\left[\mathrm{CD}+\mathrm{P}_{\mathbf{n}}\right]^{-}\right)$is expressed relative to the sum abundance of $\left[\mathrm{P}_{n}\right]^{-}$and $\left.\left[C D+P_{n}\right]^{-}\right)$is introduced as a parameter for analysis of the binding property [29]. Figure 3 shows the relation between $\left[\mathrm{CD}+\mathrm{P}_{2}\right]^{-} \%$ $\overline{\left[\mathrm{P}_{2}\right]^{-} \%+\left[\mathrm{CD}+\mathrm{P}_{2}\right]^{-} \%}$ and $[\mathrm{CD}]_{\mathrm{t}}$ (initial concentration of $\beta$-CD). At molar ratios ranging from 1:1 to $10: 1$, the value of $\frac{\left[\mathrm{CD}+\mathrm{P}_{2}\right]^{-} \%}{\left[\mathrm{P}_{2}\right]^{-} \%+\left[\mathrm{CD}+\mathrm{P}_{2}\right]^{-} \%}$ increased quickly, but the increase is slow in the $25: 1$ to $50: 1 \mathrm{M}$ ratio range. Using this expression, $\frac{\left[\mathrm{CD}+\mathrm{P}_{\mathrm{n}}\right]^{-} \%}{\left[\mathrm{P}_{\mathrm{n}}\right]^{-} \%+\left[\mathrm{CD}+\mathrm{P}_{\mathrm{n}}\right]^{-} \%}$, the repeatability of the relative intensities of the complex ion is best in all samples (Figure 4), so this parameter (hereafter abbreviated as Ir [29]) was used to determine binding constants.

Considering $\mathrm{I}_{\mathrm{r}}$ as a unique parameter, it is better to find a linear relationship between complex ion intensity

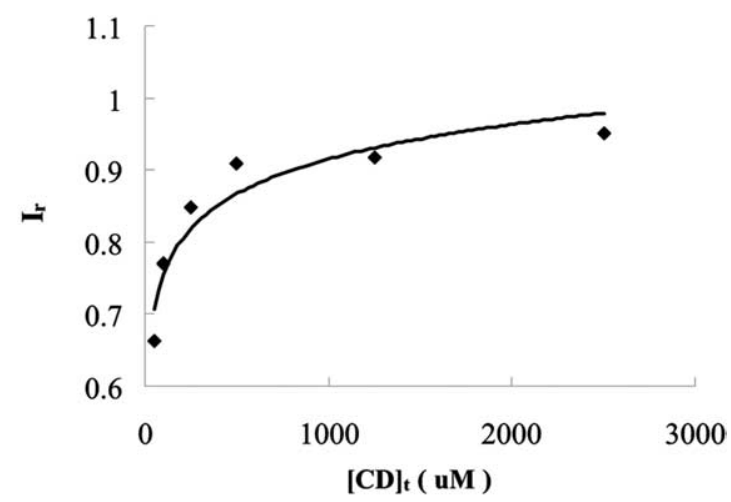

Figure 3. Effect of $[C D]_{t}$ on relative intensity $\left(\mathrm{I}_{\mathrm{r}}\right)$ of the complex ion of $\operatorname{ImPyIm} \beta \mathrm{COOH}\left(\mathbf{P}_{\mathbf{2}}\right)$ with $\beta-\mathrm{CD}$.

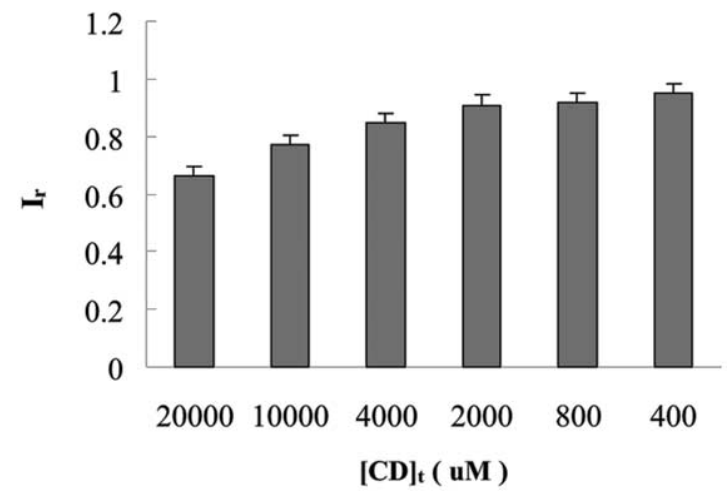

Figure 4. Repeatability of relative intensities $\left(\mathrm{I}_{\mathrm{r}}\right)$ of the complex ion between $\operatorname{ImPyIm} \beta \mathrm{COOH}\left(\mathbf{P}_{2}\right)$ and $\beta-\mathrm{CD}(n=3$ for each point).

and $[C D]_{t}$. Based on the relationship of the function in Figure 3, the reciprocal of $I_{r}$ was chosen to illustrate the effect of $\beta$-CD concentration (the reciprocal of $[C D]_{t}$ ), leading to a superior linear progression in Figure 5. Thus, a linear equation, $\mathrm{Y}=\mathrm{bX}+\mathrm{c}$, could be obtained, which describes the correlation of complex ion intensity and initial $\beta-C D$ concentrations.

\section{Evaluation of Complex Binding Constants}

Based on the linear progression in Figure 5, a double reciprocal linear eq 1 [29] was introduced for the calculation of binding constants, which is another expression of the linear equation, $\mathrm{Y}=\mathrm{bX}+\mathrm{c}$, and contains a $\mathrm{K}_{\mathrm{st}}$ factor:

$$
\frac{1}{\mathrm{I}_{\mathrm{r}}}=\frac{1}{\mathrm{k}_{\mathrm{c}}\left[\mathrm{P}_{\mathrm{n}}\right]_{\mathrm{t}} \mathrm{K}_{\mathrm{st}}[\mathrm{CD}]_{\mathrm{t}}}+\frac{1}{\mathrm{k}_{\mathrm{c}}\left[\mathrm{P}_{\mathrm{n}}\right]_{\mathrm{t}}}
$$

where $\mathrm{I}_{\mathrm{r}}$ is $\frac{\left[\mathrm{CD}+\mathrm{P}_{\mathrm{n}}\right]^{-} \%}{\left[\mathrm{P}_{\mathrm{n}}\right]^{-} \%+\left[\mathrm{CD}+\mathrm{P}_{\mathrm{n}}\right]^{-} \%}$ (relative intensity of the complex ion) and $\mathrm{I}_{\mathrm{r}}=\mathrm{k}_{\mathrm{c}}\left[\mathrm{CD}+\mathrm{P}_{\mathrm{n}}\right]^{-}$(at every molar ratio of $C D: P) ; k_{c}$ is a proportionality constant, $[C D]_{t}$ is initial concentration of $\beta-C D$, which is the same as that

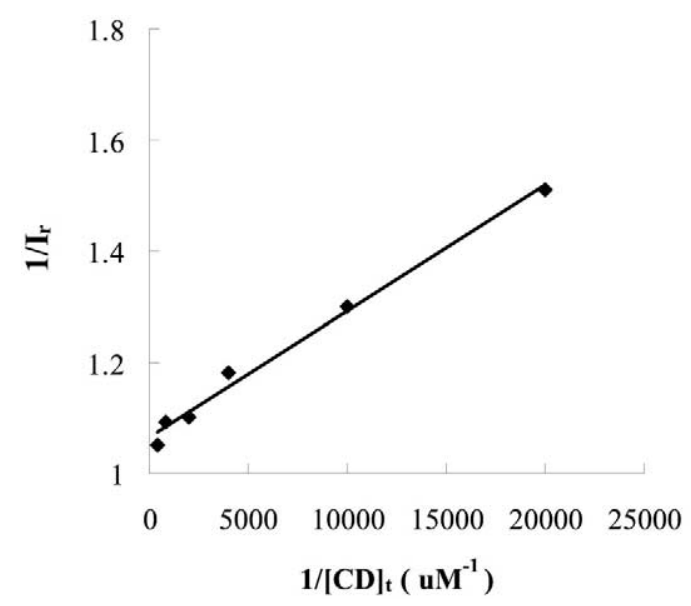

Figure 5. Effect of $1 /[C D]_{t}$ on the reciprocal of the relative intensity $\left(1 / \mathrm{I}_{\mathrm{r}}\right)$ of the complex of $\operatorname{ImPy} \operatorname{Im} \beta \mathrm{COOH}\left(\mathbf{P}_{\mathbf{2}}\right)$ with $\beta$-CD. 


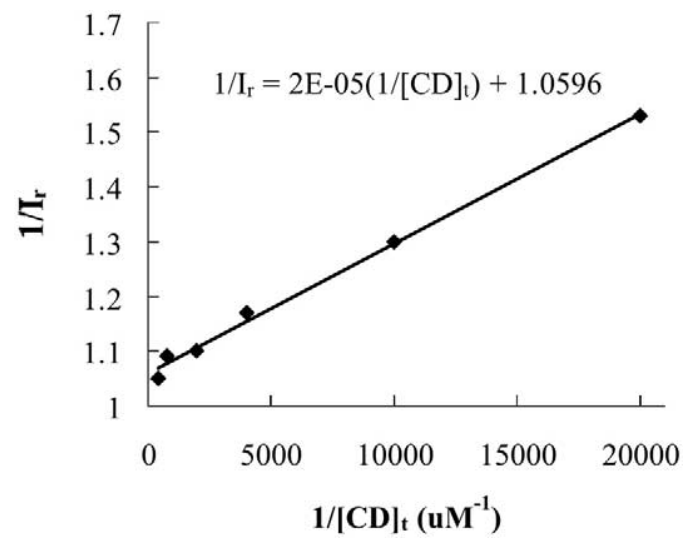

Figure 6. Effect of $1 /[C D]_{t}$ on the relative intensity $\left(1 / I_{r}\right)$ of the complex ion $\left(\left[C D+\mathbf{P}_{\mathbf{1}}\right]^{-}\right)$based on eq 1 .

in Figure $5,\left[P_{n}\right]_{t}$ is initial total concentration of polyamide acid and $K_{s t}$ is the binding constant of a 1:1 complex.

Comparing the two linear equations, $\mathrm{Y}=\mathrm{bX}+\mathrm{c}$ and eq $1, Y, X, b$, and $c$ can be defined as follows:

$$
\begin{aligned}
& \mathrm{Y}=\frac{1}{\mathrm{I}_{\mathrm{r}}} \\
& \mathrm{X}=\frac{1}{[\mathrm{CD}]_{\mathrm{t}}} \\
& \mathrm{b}=\frac{1}{\mathrm{k}_{\mathrm{c}}\left[\mathrm{P}_{\mathrm{n}}\right]_{\mathrm{t}} \mathrm{K}_{\mathrm{st}}} \\
& \mathrm{c}=\frac{1}{\mathrm{k}_{\mathrm{c}}\left[\mathrm{P}_{\mathrm{n}}\right]_{\mathrm{t}}}
\end{aligned}
$$

where $b$ is the slope and $c$ is the intercept of the equation. The ratio of $\mathrm{c}$ to $\mathrm{b}$ can be expressed as follow:

$$
\frac{\mathrm{c}}{\mathrm{b}}=\frac{\frac{1}{\mathrm{k}_{\mathrm{c}}\left[\mathrm{P}_{\mathrm{n}}\right]_{\mathrm{t}}}}{\frac{1}{\mathrm{k}_{\mathrm{c}}\left[\mathrm{P}_{\mathrm{n}}\right]_{\mathrm{t}} \mathrm{K}_{\mathrm{st}}}}=\mathrm{K}_{\mathrm{st}}
$$

Eq 6 can then be rewritten as:

$$
\mathrm{K}_{\mathrm{st}}=\frac{\mathrm{c}}{\mathrm{b}}
$$

Therefore, the binding constant $\left(\mathrm{K}_{\mathrm{st}}\right)$ can easily be calculated from the ratio of the intercept to the slope of eq 1.

In the evaluation of the complex $\left(\left[\mathrm{P}_{\mathbf{n}}+\mathrm{CD}\right]^{-}\right)$, five linear diagrams could be obtained with excellent linearity. As an example, the case of the $\left[\mathrm{P}_{\mathbf{1}}+\mathrm{CD}\right]^{-}$ion is shown in Figure 6, and a linear equation, $1 / \mathrm{I}_{\mathrm{r}}=$ $2 \mathrm{E}-05\left(1 /[\mathrm{CD}]_{\mathrm{t}}\right)+1.0596$, is obtained (where the intercept $\mathrm{c}$ is equal to 1.0596 , and the slope $\mathrm{b}$ is equal to $2 \times$ $\left.10^{-5}\right)$. The binding constant $\left(\mathrm{K}_{\mathrm{st}}\right)$ of $\left[\mathrm{P}_{\mathbf{1}}+\mathrm{CD}\right]^{-}$was calculated, from the intercept and the slope of eq 1 , based on eq 7):

$$
\mathrm{K}_{\mathrm{st}}=\frac{\mathrm{c}}{\mathrm{b}}=\frac{1.0596}{2 \mathrm{E}-05}=5.3 \times 10^{4}\left(\mu \mathrm{M}^{-1}\right)
$$

In the same way, the $\mathrm{K}_{\mathrm{st}}$ value can be obtained from the intercept and slope of a weighted least-squares regression fit of the data to eq 1 for each complex, as summarized in Table 2.

To validate the results using the double reciprocal linear equation above, a base equation (eq 8) [37] was used to calculate the binding constants. This equation is useful in determining the binding constant of a known system:

$$
\begin{aligned}
& {[\mathrm{CD}]+\left[\mathrm{P}_{\mathrm{n}}\right] \rightleftharpoons\left[\mathrm{CD}+\mathrm{P}_{\mathrm{n}}\right]} \\
& \mathrm{K}_{\mathrm{st}}=\frac{\left[\mathrm{CD}+\mathrm{P}_{\mathrm{n}}\right]}{[\mathrm{CD}]\left[\mathrm{P}_{\mathrm{n}}\right]}=\frac{\left[\mathrm{CD}+\mathrm{P}_{\mathrm{n}}\right]}{\left[\mathrm{P}_{\mathrm{n}}\right]} \times \frac{1}{\left([\mathrm{CD}]_{\mathrm{t}}-\left[\mathrm{CD}+\mathrm{P}_{\mathrm{n}}\right]\right)}
\end{aligned}
$$

where $\left[C D+P_{n}\right],[C D]$, and $\left[P_{n}\right]$ are the equilibrated concentrations of the complex, $\beta$-CD and polyamide acid, respectively. $[C D]=[C D]_{t}-\left[C D+P_{n}\right],[C D]_{t}$ is the initial concentration of $\beta$-CD. The binding constants $\left(\mathrm{K}_{\mathrm{st}}\right)$ between $\beta$-CD and the five polyamide acids were calculated based on eq 8 [37], as listed also in Table 2.

The $\mathrm{K}_{\mathrm{st}}$ values in Table 2 show good agreement between the two methods. Obviously, the double reciprocal linear eq 1 method is better for precision and simplicity. The $r^{2}$ values are $>0.93$ in all cases, indicating a good correlation between the linear equations and

Table 2. Linear equations and binding constants for polyamide acids with $\beta$-CD*

\begin{tabular}{lllll}
\hline Guest & Linear equation & $r^{2}$ & $\mathrm{~K}_{\mathrm{st}}^{\mathrm{a}} / \times 10^{4} \mathrm{M}^{-1}$ & $\mathrm{~K}_{\mathrm{st}}^{\mathrm{b}} / \times 10^{4} \mathrm{M}^{-1}$ \\
\hline \hline $\mathrm{P}_{1}$ & $(1 / \mathrm{lr})=2 \mathrm{E}-05\left(1 /[\mathrm{CD}]_{\mathrm{t}}\right)+1.0596$ & 0.99 & $5.3( \pm 0.2)$ & $5.2( \pm 1.8)$ \\
$\mathrm{P}_{2}$ & $(1 / \mathrm{lr})=2 \mathrm{E}-05\left(1 /[\mathrm{CD}]_{\mathrm{t}}\right)+1.0388$ & 0.97 & $5.2( \pm 0.2)$ & $5.1( \pm 0.7)$ \\
$\mathrm{P}_{3}$ & $(1 / \mathrm{lr})=4 \mathrm{E}-05\left(1 /[\mathrm{CD}]_{\mathrm{t}}\right)+1.2063$ & 0.99 & $3.0( \pm 0.1)$ & $3.3( \pm 1.2)$ \\
$\mathrm{P}_{4}$ & $(1 / \mathrm{lr})=4 \mathrm{E}-05\left(1 /[\mathrm{CD}]_{\mathrm{t}}\right)+1.1756$ & 0.93 & $2.9( \pm 0.1)$ & $2.8( \pm 0.3)$ \\
$\mathrm{P}_{5}$ & $(1 / \mathrm{lr})=8 \mathrm{E}-05\left(1 /[\mathrm{CD}]_{\mathrm{t}}\right)+1.7644$ & 0.93 & $2.2( \pm 0.1)$ & $0.9( \pm 0.2)$ \\
\hline
\end{tabular}

*Value is the average of three measurements

${ }^{a} K_{\text {st }}$ values calculated by eq. (1) and (7).

${ }^{\mathrm{b}} \mathrm{K}_{\mathrm{st}}$ values calculated by eq. (8). 

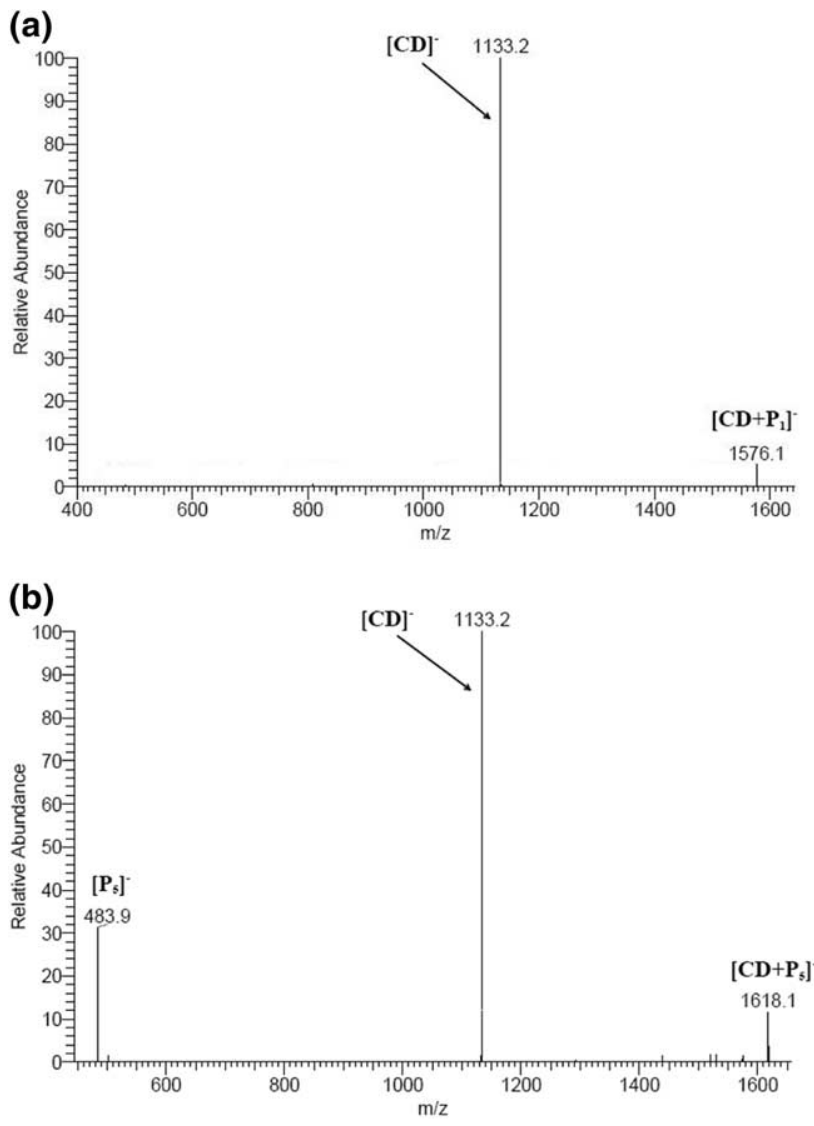

Figure 7. MS/MS spectra of $\left[\mathrm{CD}+\mathrm{P}_{\mathrm{n}}\right]^{-}$: (a) $\operatorname{ImImIm} \beta \mathrm{COOH}$ $\left(\mathbf{P}_{\mathbf{1}}\right)$ and $(\mathbf{b}) \mathrm{NO}_{2} \mathrm{PyPyPy} \beta \mathrm{COOH}\left(\mathbf{P}_{5}\right)$.

experimental values from ESI mass spectra. The $\mathrm{K}_{\mathrm{st}}$ values of the complexes are in the $10^{4}$ range; the values of $\mathbf{P}_{\mathbf{1}}$ are the maxima, while the minimum is $\mathbf{P}_{5}$. These $\mathrm{K}_{\mathrm{st}}$ values also support the fact that $N$-methylimidazole (Im) is more beneficial for binding with $\beta$-CD than $N$-methylpyrrole (Py) via hydrogen bonding, and that nitryl is unfavorable for binding of polyamide acid and $\beta$-CD.

\section{Property of Complex Ions Between $\beta$-Cyclodextrin and Polyamide Acids}

Fragmentation and stability of the complex ions were investigated by MS/MS spectra. In MS/MS spectra analysis, the fragmentations of $\left[\mathrm{CD}+\mathrm{P}_{\mathbf{n}}\right]^{-}$appeared when the CID energy increased to $\sim 20 \%$, which suggested that the complex ions of $\beta$-CD and polyamide acids are stable. Representative MS/MS spectra of the complex ions ([CD $\left.+\mathrm{P}_{\mathrm{n}}\right]^{-}$) are shown in Figure 7. In the case of $\operatorname{ImImIm} \beta \mathrm{COOH}\left(\mathbf{P}_{\mathbf{1}}\right),\left[\mathrm{CD}+\mathrm{P}_{1}\right]^{-}$dissociated into $\beta$-CD and $\mathbf{P}_{\mathbf{1}}$, and only $[C D]^{-}$was observed at $\mathrm{m} / z$ 1133.2. In the case of $\mathrm{NO}_{2} \mathrm{PyPyPy} \beta \mathrm{COOH}\left(\mathbf{P}_{5}\right),\left[\mathrm{CD}+\mathrm{P}_{5}{ }^{-}\right.$dissociated into $[C D]^{-}$and $\left[\mathrm{P}_{5}\right]^{-}$, which were both observed in the MS/MS spectrum. The complex ions of other polyamide acids also generated $[\mathrm{CD}]^{-}$ion only in the MS/MS spectra of $\left[\mathrm{CD}+\mathrm{P}_{2}\right]^{-}$, $\left[\mathrm{CD}+\mathrm{P}_{3}\right]^{-}$, and $\left[\mathrm{CD}+\mathrm{P}_{4}\right]^{-}$. These results suggested that the nitryl induced polyamide $\mathbf{P}_{5}$ to yield a negative ion by the loss of a proton.

The use of capillary heating to dissociate the complex could provide additional information regarding the properties of complex ions between $\beta$-cyclodextrin and polyamide acids in the gas-phase [38-40]. In this study, capillary temperature was increased from 150 to $400{ }^{\circ} \mathrm{C}$ to examine the thermo-stability of $\left[C D+P_{n}\right]^{-}$. The experimental results show that the complex ions remained dominant in ESI mass spectra, even when the temperature was increased to $400{ }^{\circ} \mathrm{C}$. Consequently, the binding of $\beta-\mathrm{CD}$ and polyamide acids $\left(\left[\mathrm{CD}+\mathrm{P}_{\mathbf{n}}\right]^{-}\right)$is thermodynamically stable.

With respect to the 1:1 complex ion, it was noticeable that the 2:1 or 1:2 complex ions could be observed, but were very weak and were only observed when $\beta$-CD or $\mathbf{P}_{\mathbf{n}}$ was in excess. For example, when the ratio $\beta-C D / \mathbf{P}_{\mathbf{1}}$ was increased to $50: 1$, the $\left[2 \mathrm{CD}+\mathrm{P}_{\mathbf{1}}\right]$ complex ion could be observed $(<5 \%)$ in ESI spectrum, which indicated that 1:1 complexes were the dominant binding mode compared with the 2:1 complexes, even at the highest $\beta$-CD concentration (50:1 $\mathrm{M}$ ratio). In addition, the intensities of 2:1 and 1:2 complex ions decreased when capillary temperature increase and, subsequently, disappeared at $300{ }^{\circ} \mathrm{C}$. Therefore, $2: 1$ and $1: 2$ complex ions are thermodynamically unstable.

\section{Conclusions}

The present work has demonstrated the ability of ESI-MS to provide strong evidence for noncovalent binding between polyamide acids and $\beta$-CD. The 1:1 binding mode was indicated initially by examining the binding stoichiometry from ESI mass spectra. The method simultaneously gives binding affinity in the form of binding constants, based on a novel linear equation, and shows that polyamide acids with $\beta$-CD have binding affinities in the order: $\operatorname{ImImIm} \beta \mathrm{COOH}>$ $\operatorname{ImPyIm} \beta \mathrm{COOH}>\operatorname{ImPyPy} \beta \mathrm{COOH}>\mathrm{PyPyPy} \beta \mathrm{COOH}$ $>\mathrm{NO}_{2} \mathrm{PyPyPy} \beta \mathrm{COOH}$. In addition, sample consumption is less than $1 \mathrm{nmol}$ per analysis, which makes this method useful when only small amounts of sample are available.

\section{Acknowledgments}

This project is supported by the National Natural Science Foundation of China (nos. 20272005 and 20472009).

\section{References}

1. Yuan, G.; Xiao, J. H.; Huang, W. Q.; Tang, F.; Zhou, Y. Synthesis of Polyamides Containing $N$-Methylpyrrole and $N$-Methylimidazole and Their Anticancer Activity. Arch. Pharm. Res. 2002, 25, 585-589.

2. Dervan, P. B.; Burli, R. W. Sequence-Specific DNA Recognition by Polyamides. Curr. Opin. Chem. Biol. 1999, 3, 688-693.

3. Xiao, J. H.; Yuan, G.; Huang, W. Q.; Chan, A. S. C.; Lee, K. L. D. A Convenient Method for the Synthesis of DNA-Recognizing Polyamides in Solution. J. Org. Chem. 2000, 65, 5506-5513.

4. Szejtli, J. Introduction and General Overview of Cyclodextrin Chemistry. Chem. Rev. 1998, 98, 1743-1753.

5. Hedges, A. R. Industrial Applications of Cyclodextrins. Chem. Rev. 1998, 98, 2035-2044. 
6. Uekama, K.; Hirayama, F.; Irie, T. Cyclodextrin Drug Carrier Systems. Chem. Rev. 1998, 98, 2045-2076.

7. Redenti, E.; Szente, L.; Szejtli, J. Cyclodextrin Complexes of Salts of Acidic Drugs: Thermodynamic Properties, Structural Features, and Pharmaceutical Applications. J. Pharm. Sci. 2001, 90, 979-986.

8. Gabelica, V.; Galic, N.; De Pauw, E. On the Specificity of Cyclodextrin Complexes Detected by Electrospray Mass Spectrometry. J. Am. Soc. Mass Spectrom. 2002, 13, 946-953.

9. Loukas, Y. L.; Jayasekera, P.; Gregoriadis, G. Characterization and Photoprotection Studies of a Model $\gamma$-CyclodextrinIncluded Photolabile Drug Entrapped in Liposomes Incorporating Light Absorbers. J. Phys. Chem. 1995, 99, 11035-11040.

10. Redenti, E.; Szente, L.; Szejtli, J. Cyclodextrin Complexes of Salts of Acidic Drugs. Thermodynamic Properties, Structural features, and Pharmaceutical Applications. J. Pharm. Sci. 2001, 90, 979-986.

11. Bongiorno, D.; Ceraulo, L.; Mele, A.; Panzeri, W.; Selva, A.; Liveri, V. T. Structural and Physicochemical Characterization of the Inclusion Complexes of Cyclomaltooligosaccharides (Cyclodextrins) with Melatonin. Carbohydr. Res. 2002, 337, 743-754

12. Connors, K. A.; Pendergast, D. D. Microscopic Binding Constants in Cyclodextrin Systems: Complexation of $\alpha$-Cyclodextrin with Sym-1,4-Disubstituted Benzenes. I. Am. Chem. Soc. 1984, 106, 7607-7614.

13. Loukas, Y. L. Multiple Complex Formation of Fluorescent Compounds with Cyclodextrins: Efficient Determination and Evaluation of the Binding Constant with Improved Fluorometric Studies. J. Phys. Chem. B 1997, 101, 4863-4866.

14. Loukas, Y. L.; Vyza, E. A.; Valiraki, A. P. Inclusion Complexes and Stability Studies of an Organophosphorus Insecticide with Cyclodextrins-Spectrophotometric and Kinetic Determination of Stability Constant. Analyst 1995, 120, 533-538.

15. Loukas, Y. L. Measurement of Molecular Association in Drug: Cyclodextrin Inclusion Complexes with Improved $\mathrm{H}^{1}$ NMR Studies. J. Pharm. Pharmacol. 1997, 49, 944-948.

16. Dotsikas, Y.; Kontopanou, E.; Allagiannis, C.; Loukas, Y. L. Interaction of 6-p-Toluidinylnaphthalene-2-Sulphonate with $\beta$-Cyclodextrin. J. Pharm. Biomed. Anal. 2000, 23, 997-1003.

17. Selva, A.; Redenti, E.; Zanol, M.; Ventura, P.; Casetta, B. A Study of $\beta$-Cyclodextrin and Its Inclusion Complexes with Piroxicam and Terfenadine by Ionspray Mass Spectrometry. Org. Mass Spectrom. 1993, 28, 983.

18. Przybylski, M.; Glocker, M. O. Electrospray Mass Spectrometry of Biomacromolecular Complex with Noncovalent Interactions-New Analytical Perspectives for Supramolecular Chemistry and Molecular Recognition Process. Angew. Chem. Int. Ed. Engl. 35, 1996, 807-826.

19. Srinivasan, K.; Bartlett, M. G. Comparison of Cyclodextrin-Barbiturate Noncovalent Complexes Using Electrospray Ionization Mass Spectrometry and Capillary Electrophoresis. Rapid Commun. Mass Spectrom. 2000, $14,624-632$.

20. Selva, A.; Redenti, E.; Ventura, P.; Zanol, M.; Casetta, B. Study of $\beta$-Cyclodextrin-Ketoconazole-Tartaric Acid Multicomponent Noncovalent Association by Positive and Negative Ionspray Mass Spectrometry. J. Mass Spectrom. 1998, 33, 729

21. Bongiorno, D.; Ceraulo, L.; Mele, A.; Panzeri, W.; Selva, A.; Liveri, V. T. Guest-to-host Proton Transfer in Melatonin- $\beta$-Cyclodextrin Inclusion Complex by Ionspray Fast Atom Bombardment and Tandem Mass Spectrometry. J. Mass Spectrom. 2001, 36, 1189-1194.

22. Madhusudanan, K. P.; Katti, S. B.; Dwivedi, A. K. Noncovalent Complexes of Nucleosides and Nucleobases with $\beta$-Cyclodextrin: A Study by Fast Bombardment Mass Spectrometry and Collision Induced Dissociation. J. Mass Spectrom. 1998, 33, 1017.

23. Mele, A.; Panzeri, W.; Selva, A.; Mauri, P. Fast Atom Bombardment, Electrospray, Ionspray, and Tandem Mass Spectrometry of 1:1 $\beta$-Cyclo-
dextrin/5-Methoxytryptamine Hydrochloride Host-Guest Complex: Host Protonation and Fragmentation Due to Guest Deamination. Eur. J. Mass Spectrom. 2000, 6, 169-174.

24. Guo, M.; Zhang, S.; Song, F.; Wang, D.; Liu, Z.; Liu, S. Studies on the Noncovalent Complexes Between Oleanolic Acid and Cyclodextrins Using Electrospray Ionization Tandem Mass Spectrometry. J. Mass Spectrom. 2003, 38, 723-731.

25. Parker, D.; Kataky, R. Selective Complexation and Sensitive Analysis of Charge Diffuse Cationic Species Using Lipophilic Cyclodextrins. J. Chem. Soc. Chem. Commun. 1997, 2, 141-145.

26. Penn, S. G.; He, F.; Green, M. K.; Lebrilla, C. B. The Use of Heated Capillary Dissociation and Collision-Induced Dissociation to Determine the Strength of Noncovalent Bonding Interactions in Gas-Phase Peptide-Cyclodextrin Complexes. J. Am. Soc. Mass Spectrom. 1997, 8, 244-252.

27. Cheng, Y.; Hercules, D. M. Measurement of Chiral Complexes of Cyclodextrins and Amino Acids by Electrospray Ionization Time-of-Flight Mass Spectrometry. J. Mass Spectrom. 2001, 36, 834-836.

28. Lamcharfi, E.; Chuilon, S.; Kerbal, A.; Kunesch, G.; Libot, F.; Virelizier, H Electrospray Ionization Mass Spectrometry in Supramolecular Chemistry: Characterization of Noncovalent Cyclodextrin Complexes. J. Mass Spectrom. 1996, 31, 982-986.

29. Dotsikas, Y.; Loukas, Y. L. Efficient Determination and Evaluation of Model Cyclodextrin Complex Binding Constants by Electrospray Mass Spectrometry. J. Am. Soc. Mass Spectrom. 2003, 14, 1123-1129.

30. Liu, F. Y.; Kildsig, D. O.; Mirta, A. K. $\beta$-Cyclodextrin/Steroid Complexation: Effect of Steroid Structure on Association Equilibria. Pharm. Res. 1990, 7, 869-873.

31. Rajewski, R. A.; Stella, V. J. Pharmaceutical Applications of Cyclodextrins. 2. In vivo Drug Delivery. J. Pharm. Sci. 1996, 85, 1142-1169.

32. Selva, A.; Redenti, E.; Zanol, M.; Ventura, P.; Casetta, B. A Study of $\beta$-Cyclodextrin and Its Inclusion Complexes with Piroxicam and Terfenadine by Ionspray Mass Spectrometry. Org. Mass Spectrom. 1993, 28, 983-986.

33. Bakhtiar, R.; Hop, C. E. C. A. A Study of the Complexation Between Dimethyl- $\beta$-Cyclodextrin and Steroid Hormones Using Electrospray Ionization Mass Spectrometry. Rapid Commun. Mass Spectrom. 1997, 11, $1478-1481$

34. Sun, W.; Cui, M.; Liu, S.; Song, F.; Elkin, Y. N. Electrospray Ionization Mass Spectrometry of Cyclodextrin Complexes with Amino Acids in Incubated Solutions and in Eluates of Gel Permeation Chromatography. Rapid Commun. Mass Spectrom. 1998, 12, 2016-2022.

35. Wan, K. X.; Shibue, T.; Gross, M. L. Noncovalent Complexes Between DNA-Binding Drugs and Double-Stranded Oligodeoxynucleotides: A Study by ESI Ion-Trap Mass Spectrometry. J. Am. Chem. Soc. 2000, 122, 300-307.

36. Gabelica, V.; De Pauw, E.; Rosu, F. Interaction Between Antitumor Drugs and a Double-Stranded Oligonucleotide Studied by Electrospray Ionization Mass Spectrometry. J. Mass Spectrom. 1999, 34, 1328-1337.

37. De Vriendt, K.; Sandra, K.; Desmet, T.; Nerinckx, W.; Van Beeumen, J.; Devreese, B. Evaluation of Automated Nano-Electrospray Mass Spectrometry in the Determination of Noncovalent Protein-Ligand Complexes. Rapid Commun. Mass Spectrom. 2004, 18, 3061-3067.

38. Daniel, J. M. Friess, S. D.; Rajagopalan, S. Wendt, S. Zenobi, R. Quantitative Determination of Noncovalent Binding Interactions Using Soft Ionization Mass Spectrometry. Int. J. Mass Spectrom. 2002, 216, 1-27.

39. He, F.; Ramirez, J.; Garcia, B. A.; Lebrilla, C. B. Differentially Heated Capillary for Thermal Dissociation of Noncovalently Bound Complexes Produced by Electrospray Ionization. Int. J. Mass Spectrom. 1999, 182, 261-273.

40. Garcia, B.; Ramirey, J.; Wong, S. Lebrilla, C. B. Thermal Dissociation of Protonated Cyclodextrin-Amino Acid Complexes in the Gas Phase. Int. J. Mass Spectrom. 2001, 210/211, 215-222. 